\title{
STAKEHOLDERS' PERCEPTIONS ABOUT FIRE IMPACTS ON LITHUANIAN PROTECTED AREAS
}

\author{
Paulo Pereira ${ }^{1 *}$, Pranas Mierauskas $^{1}$, Agata Novara $^{2}$ \\ ${ }^{1}$ Environmental Management Center, Mykolas Romeris University, Ateities g. 20, LT-08303 Vilnius, Lithuania \\ ${ }^{2}$ Dipartimento di Scienze Agrarie e Forestali, University of Palermo, Viale delle Scienze, 90128 Palermo, Italy
}

Received: 8 April 2014; Accepted: 8 April 2014

\begin{abstract}
The aim of this work is to study Lithuanian stakeholders' perceptions of fire impacts in protected areas. For this study, the stakeholders consisted of foresters, ecologists and farmers. A clear understanding of the opinions of stakeholders about fire effects on environmental, social and economic aspects of Lithuanian protected areas will allow an assessment of the stakeholders' reaction to fire policy, including government measures towards fire prevention, suppression and application of prescribed fire to landscape management. The results showed that stakeholders in general think that fire is not a threat to Lithuania and to the ecological processes in the protected areas. However, they agree that fires have negative impacts on soil properties and fertility but are not to an irremediable or irrecoverable extent. Stakeholders disagree that fire has positive consequences for agricultural and cattle activities but agreed that vegetation recovers quickly. They do not see fire as a social and economic problem, do not agree that prescribed fire could be used to landscape management, and believe that mechanical thinning is a better management tool than prescribed fire. Stakeholders agree that fire does not have negative impacts on the biodiversity. These opinions depended on the age group of the respondent but especially on the respondent's professional occupation. Copyright (C) 2014 John Wiley \& Sons, Ltd.
\end{abstract}

KEYWORDS: $\quad$ stakeholders; protected areas; soil; prescribed fire; biodiversity

\section{INTRODUCTION}

Stakeholders and public perception are key aspects in policy and decision-making. Public perception often drives the activities of our society. It is strongly recognized that public involvement is fundamental to effective territorial planning. When combined with local knowledge, scientific research can contribute to a better understanding of the complexity and dynamic behaviour of a system. Integrating both knowledge bases encourages the investigation of potential uncertainties, the development of a more rigorous analysis (Reed, 2008; Mekuria \& Aynekulu, 2013; Jones et al., 2014; Tesfaye et al., 2014; Mulale et al., 2014) and enhances the planning process effectiveness (Gadgil \& Ede, 1998; Bewket \& Sterk, 2002; Reed et al., 2007; Reynolds et al., 2011; Nabahungu \& Visser, 2013; Fleskens \& Stringer, 2014). Previous studies have shown that integration between science and local knowledge positively influences the social, economic and environmental aspects of local communities (Özgüner et al., 2012; Karltun et al., 2013; Nabahungu \& Visser, 2013; Sop \& Oldeland, 2013; Bisaro et al., 2014; De Pina Tavares et al., 2014). In addition, public participation in policy making has important advantages in the democratic development and implementation of management actions. The citizens feel more responsible for the decisions, the

\footnotetext{
* Correspondence to: P. Pereira, Environmental Research Center, Mykolas Romeris University, Ateities g. 20, LT-08303 Vilnius, Lithuania.

E-mail: Paulo@mruni.eu
}

dialogue among the different stakeholders is increased, and debate and exchange of ideas are encouraged. All these aspects add an important value to the legitimacy of the decisions that are implemented. One negative aspect of public participation is that not all stakeholders have equal representation (Michels \& DeGraaf, 2010; Stringer \& Harris, 2013; McDonagh et al., 2014).

Fire is recognized to be a global phenomenon with positive and negative impacts on ecosystems. It is a strong evolutionary force that has shaped global biomes and is fundamental for human existence, evolution and development. Thus, the world as we know it today cannot be understood without acknowledging the influence of fire. Boreal forests, eucalypt woodlands, scrublands, savannas and grasslands are considered flammable ecosystems (Bond \& Keeley, 2005; Pausas \& Keeley, 2009). According to Granström (2001), fire is common in boreal ecosystems, and it has had a strong impact on the distribution of plants. Some species of plants and insects are fire dependent and colonize recently burned patches. If fire is not present in boreal ecosystems, in the long term, the species associated with fire could be lost.

Nowadays, because of climate change, wildfire size, frequency and severity are changing the resilience of ecosystems to respond to fire disturbance, especially in temperate and boreal regions, where the warmer trends are more evident (Flannigan et al., 2009). Together with climate change, social changes such as rural abandonment and migration to urban areas and fire suppression policies are 
inducing important changes in these ecosystems. These changes favour the increase of biomass in the forests, which contributes to the vulnerability of ecosystems to wildfires. The lack of forest management and fire suppression is viewed by many studies as the main cause of the increase in wildfires (Pausas et al., 2009; Van Berkel et al., 2011; Ruiz-Mirazo et al., 2012; Pereira et al., 2012a; Mierauskas \& Pereira, 2013; Moreno et al., 2014; Carreiras et al., 2014) and the primary contribution to land degradation (Pérez-Cabello et al., 2010; Novara et al., 2011; Aznar et al., 2014).

Wildfires have important impacts on society and economy such as life and property loss and effects on health and the temporary or permanent reduction of population well-being (Meyn et al., 2007; Mavsar et al., 2010). It is well known that human activities are responsible for the majority of wildfires (Martinez et al., 2009; Ganteaume et al., 2013). These facts, together with the media news coverage, portray fire in a negative light. Most of the information about fire is not based on scientific knowledge, and it creates the public perception that there is a need for fire exclusion and suppression (Pereira et al., 2010; Donovan et al., 2011). After seeing catastrophic images of fire in the media, the public adopts the idea that fire damages in ecosystems are irreversible, which is not always true, because some ecosystems are very resilient and can recover quickly (Riano et al., 2002; Pausas et al., 2009; Pereira et al., 2013a, 2013c).

Normally, the stakeholders' perceptions are related to non-ecological factors (e.g. the landscape aesthetic after the fire) (Constanza \& Moody, 2011), and very often, stakeholders consider fire as one of the major causes of land degradation (Carvalho et al., 2002; Davies et al., 2010; Sop \& Oldeland, 2013). However, frequently, there is a lack of real participation of stakeholders in wildland fire management decisions (Aguilar \& Montiel, 2011). Fire is an important natural disturbance, and it is fundamental that stakeholders know the positive and negative aspects of it (Zaksek \& Arvai, 2004). Fire has been used by humans for land management for centuries throughout Europe (Lazaro, 2010). The ecological benefits of the application of periodic fire to the landscape are to as follows: (i) enhance wildlife habitat; (ii) create more resilient ecosystems; (iii) reduce the understory vegetation; (iv) increase the amount of nutrients in the soil; (v) control pests and harmful insects; and (vi) improve pastures for grazing and the wildfire. In addition, the use of fire as a management tool reduces the costs of pre-fire fuel reduction and fire suppression (Brockway \& Outcalt, 2000). The biggest disadvantages of fire use are the smoke emissions and the risk of fire escape from the prescribed boundaries (Stephens \& Moghaddas, 2005).

The acceptance of prescribed and wildland fires as important ecologic processes for landscape management is not fully understood. Different views on the ecological value of fire are a source of conflicts among stakeholders with different socio-environmental values (Mierauskas \& Pereira, 2013; Ryan et al., 2013), especially relevant in protected areas (Turner, 1999). In the USA, the public and other stakeholders increasingly accept the use of fire as a management tool and recognize the benefits of it (Zaksek \& Arvai, 2004; Stone et al., 2010). In Europe, prescribed fire is not allowed in all countries, despite the recognition of its use as a traditional practice (Lazaro \& Montiel, 2010).

In Lithuania, fire has been used as a traditional tool for landscape management by rural populations in the countryside and inside the protected areas. However, the first legal prescribed fire in a protected area was only authorized recently (Pereira et al., 2012b). Despite the approval of prescribed fire, this practice is not fully adopted, and very often, farmers illegally burn their fields resulting in property loss because fire frequently escapes from control (Mierauskas, 2012). The aim of this work is to study the stakeholders' perception of fire in Lithuanian protected areas and the potential use of prescribed fire in landscape management.

\section{MATERIALS AND METHODS}

\section{Study Site}

Lithuania is located in Eastern Europe and has an area of $65300 \mathrm{~km}^{2}$. It is bordered by Latvia, Belarus, Russia and Poland. The landscape is primarily flat, and the highest point reaches $294 \mathrm{~m}$ asl. The climate is continental, and the annual average temperature can vary across the territory from 5.5 to $7.0^{\circ} \mathrm{C}$ and the annual average rainfall from 550 to $990 \mathrm{~mm}$ (Bukantis, 2001).

Lithuanian protected areas are divided into state strict reserves (culture and nature), reserves (state and municipal), recuperational plots, national parks, regional parks, biosphere reserves and biosphere polygons, with different regimes of protection and management. In total, Lithuania has 463 protected areas, which occupy $15.7 \%$ of the territory (Table I). According to the protected area classification, the state and municipal reserves are the most numerous $(84.23 \%)$ and biosphere reserves the least $(0.22 \%)$. Regional parks occupy the major part of the protected area space $(44 \%)$ and recuperational plots $(0.1 \%)$ the least (Table I). In the strict reserves, the most important land use, according to the Coordination of Information on the Environment land cover classification, is forest (57\%) followed by agricultural areas $(19 \%)$, water bodies $(17 \%)$, others $(5 \%)$, peatlands (1\%) and artificial covers $(1 \%)$. The land use coverage is similar for regional parks. Forests are also the major land use (44\%), followed by agricultural areas (37\%), water bodies (10\%), others (4\%), peatlands (3\%) and artificial cover $(2 \%)$. Pine (Pinus sylvestris) is the most common species in the national parks, strict and biosphere reserves (Figure 1).

Since 2004, Lithuania has been a member of the European Union, and several sites were classified under Birds Directive (79/409/EEC) and Habitats Directive (92/43/EEC). It also became part of the Natura 2000 network. The Habitats Directive is an important legal instrument at the European level, which aims to provide legal protection for habitats and species with European relevance. This network is composed of Special Areas of Conservation and Special Protection Areas (http://ec.europa.eu/environment/nature/natura2000/). 
Table I. Protected area type, area, $\%$ of the country and degree of protection and management

\begin{tabular}{|c|c|c|c|c|c|c|c|}
\hline & $\begin{array}{l}\text { Protected } \\
\text { area type }\end{array}$ & Number & Area (ha) & $\begin{array}{l}\% \text { of the total } \\
\text { protected areas } \\
\text { by type }\end{array}$ & $\begin{array}{l}\% \text { of the total } \\
\text { protected areas } \\
\text { by area }\end{array}$ & $\begin{array}{l}\% \text { of the } \\
\text { country } \\
\text { area }\end{array}$ & Degree of protection and management $\mathrm{t}^{\mathrm{a}}$ \\
\hline 1 & $\begin{array}{l}\text { Strict reserves } \\
\text { (culture and } \\
\text { nature) }\end{array}$ & 6 & 18772.09 & 1.30 & 1.84 & 0.29 & $\begin{array}{l}\text { 'Set up in order to preserve and } \\
\text { conduct research of the natural or } \\
\text { cultural territorial complexes of } \\
\text { particular scientific value, ensure the } \\
\text { unaffected course of natural processes } \\
\text { or maintenance of authenticity of } \\
\text { cultural properties, promote protection } \\
\text { of the territorial complexes of natural } \\
\text { and cultural heritage. The } \\
\text { conservational main mode of land use } \\
\text { shall be established in these areas with } \\
\text { termination of economic activities } \\
\text { therein' }\end{array}$ \\
\hline 2 & $\begin{array}{l}\text { Reserves } \\
\text { (state and } \\
\text { municipal } \\
\text { reserves) }\end{array}$ & 300 & 157563.97 & 84.23 & 15.28 & 2.39 & $\begin{array}{l}\text { 'Established for the preservation of the } \\
\text { natural and/or cultural sites valuable } \\
\text { from the scientific or cognitive point of } \\
\text { view, the territorial complexes and } \\
\text { objects (properties) of natural and } \\
\text { cultural heritage located therein, } \\
\text { landscape and biological diversity as } \\
\text { well as gene pool. Preservation of the } \\
\text { properties located in these areas shall } \\
\text { be ensured without terminating } \\
\text { economic activities therein.' }\end{array}$ \\
\hline 3 & $\begin{array}{l}\text { Recuperational } \\
\text { plots }\end{array}$ & 3 & 875.42 & 0.65 & 0.09 & 0.01 & $\begin{array}{l}\text { 'Intended for the protection, } \\
\text { restoration, enhancement of the } \\
\text { species of natural resources or } \\
\text { complexes thereof which have been } \\
\text { impoverished by activities and for } \\
\text { restricted use of natural resources' }\end{array}$ \\
\hline 4 & National parks & 5 & 144338.5 & 6.48 & 14 & 2.21 & $\begin{array}{l}\text { 'Established in the areas which are } \\
\text { complex from the natural, cultural and } \\
\text { recreational points of view and are } \\
\text { particularly valuable and whose } \\
\text { protection and management is related } \\
\text { to designation of an areas' functional } \\
\text { and landscape management zones.' }\end{array}$ \\
\hline 5 & Regional parks & 30 & 449363.59 & 1.08 & 44 & 6.88 & $\begin{array}{l}\text { 'Established for the protection of the } \\
\text { landscape and ecosystems of regional } \\
\text { significance from the natural, cultural } \\
\text { and recreational point of view, } \\
\text { regulation of their recreational and } \\
\text { economic use. Historical national } \\
\text { parks shall be established for the } \\
\text { preservation of most valuable } \\
\text { historical regional complexes and their } \\
\text { natural environment' }\end{array}$ \\
\hline 6 & $\begin{array}{l}\text { Biosphere } \\
\text { reserves }\end{array}$ & 1 & 18489.69 & 0.22 & 2 & 0.28 & $\begin{array}{l}\text { 'Established for the global and } \\
\text { regional monitoring of biosphere and }\end{array}$ \\
\hline 7 & $\begin{array}{l}\text { Biosphere } \\
\text { polygons }\end{array}$ & 28 & 236648.95 & 6.05 & 23 & 3.58 & $\begin{array}{l}\text { conducting of environmental } \\
\text { experiments, also for the preservation } \\
\text { of the natural complexes located } \\
\text { therein' }\end{array}$ \\
\hline & Total & 463 & 1026072.37 & & & 15.7 & \\
\hline
\end{tabular}

Source: State Service of Protected Areas under the Ministry of Environment, 2013

${ }^{a}$ Definitions of the of protection and management based on the Republic of Lithuania law on protected areas, December 2011, No IX-628

In Lithuania, Natura 2000 sites cover a terrestrial area of $7,879 \mathrm{~km}^{2}(12.07 \%$ of the terrestrial national territory) and a marine area of $15 \mathrm{~km}^{2}$ ( $8 \%$ of the marine national territory).
In 2010, Lithuania had a total of 488 sites inside the Natura 2000 network (http://ec.europa.eu/environment/nature/natura2000/ db_gis/index_en.htm). Most of the area in designed sites 
a)

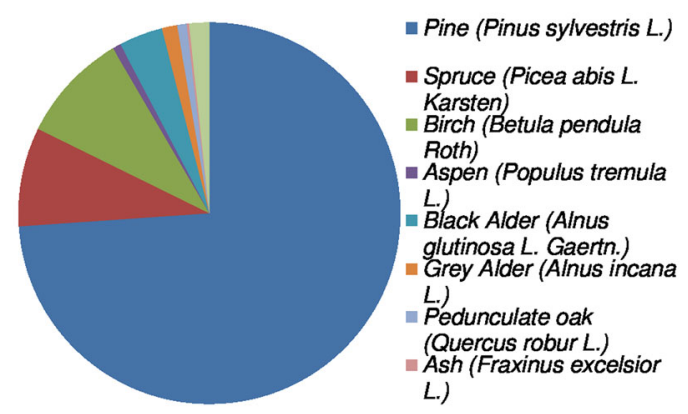

b)

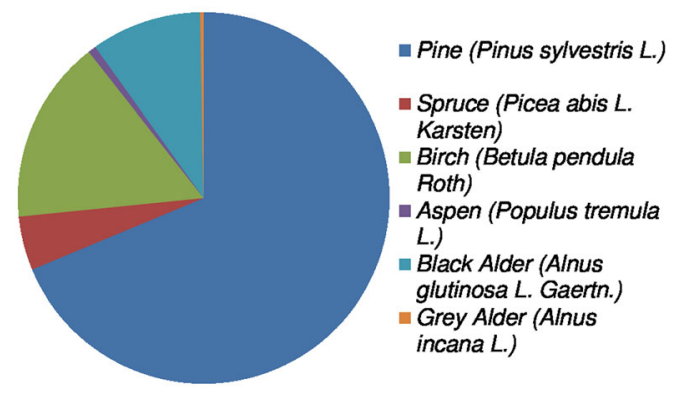

Figure 1. Percentage of tree species distribution in (a) national parks and (b) strict and biosphere reserves (State Service of Protected Areas under the Ministry of Environment, 2012). This figure is available in colour online at wileyonlinelibrary.com/journal/ldr

overlaps the national existing protected areas, although the Lithuanian national system of protected areas covers a greater area than Natura 2000 designed sites.

\section{Stakeholder Interviews}

This work presents the findings of a survey carried out among Lithuanian protected area public and private stakeholders in the spring and summer of 2013. One hundred and forty-seven stakeholders were contacted by telephone and email. A total of 76 surveys were answered/returned with a response rate of $52 \%$. The objective of the questionnaire was to understand if stakeholders perceived the economic, environmental and social dimensions of fire impacts and to assess the acceptance of the use of prescribed fire in the management of protected areas. All questions were asked in the context of the Lithuanian protected areas where the stakeholders have interests. The stakeholders that answered the survey were foresters, ecologists and farmers with economic and conservationist interests in the Lithuanian protected areas. No other groups were considered because they did not return the questionnaire. We designed a closed-question questionnaire with 12 questions. Questions posed to the respondents are listed in Table II, and the respondents were asked to rank answers to questions with numbers $1-5(1=$ strongly disagree, $2=$ disagree, $3=$ slightly agree, $4=$ agree and $5=$ strongly agree). Data analyses were carried out considering the age group and the profession of respondents.
Table II. Questions posed to the participants

\begin{tabular}{|c|c|}
\hline \multicolumn{2}{|c|}{ Question } \\
\hline 1 & Fire is a threat \\
\hline 2 & Fire represents an ecological problem \\
\hline 3 & Fire causes problems in soil properties and fertility \\
\hline 4 & $\begin{array}{l}\text { Fires have negative impacts on natural resources and } \\
\text { ecosystems }\end{array}$ \\
\hline 5 & Fires have irremediable and irrecoverable impacts \\
\hline 6 & $\begin{array}{l}\text { Grassland fires have positive implications for } \\
\text { agricultural and cattle activities }\end{array}$ \\
\hline 7 & Vegetation recovers quickly after fire \\
\hline 8 & $\begin{array}{l}\text { Fires cause important social and economic problems in } \\
\text { rural areas }\end{array}$ \\
\hline 9 & $\begin{array}{l}\text { Government should invest more funds in ecosystems } \\
\text { protection against fire }\end{array}$ \\
\hline 10 & $\begin{array}{l}\text { Prescribed fire can be used for landscape management } \\
\text { and reduce wildfire risk }\end{array}$ \\
\hline 11 & $\begin{array}{l}\text { Prescribed fire is a better tool for landscape } \\
\text { management than vegetation mechanical thinning }\end{array}$ \\
\hline 12 & Fires have negative impacts on biodiversity \\
\hline
\end{tabular}

All the questions were in the context of Lithuanian protected areas.

\section{Statistical Analyses}

The relative percentage of the answers to each question was calculated considering all the respondents. The normality and heteroscedasticity of the data distributions were tested with the Kolmogorov-Smirnov test and the Levene test respectively. Data normality and heteroscedasticity were considered at a $p>0.05$. Data did not follow the normal distribution or the homogeneity of the variances. Thus, data were log-normal transformed in order to meet the previous requirements. With the transformed data, a one-way ANOVA test was applied in order to identify significant differences among age group and profession. Significant differences were considered at $p<0.05$. If significant differences were identified, a Tukey honestly significant difference post hoc test was carried out in order to identify differences within groups. Using the log-normal transformed data, a principal component analysis (PCA) was carried out using a varimax rotation based on the correlation matrix in order to identify the relationship among the variables, age and profession. Statistical analyses were carried out using Statistica 7.0 for Windows.

\section{RESULTS}

The distribution of the age groups of the respondents was 20-30 (22\%), 31-40 (41\%), 41-50 (25\%) and 51-60 $(12 \%)$. In relation to the professions, $47 \%$ were ecologists, $11 \%$ farmers and $42 \%$ foresters. A higher percentage of the participants were male subjects $(79 \%)$. The percentages of answers in each category for the 12 questions are presented in Table III. The majority of the respondents $(41 \%)$ disagreed that fire is a threat in Lithuania or that it is an ecological problem (38\%). However, the largest percentage of the respondents $(34 \%)$ slightly agreed that fire has negative impacts on soil properties and fertility 
Table III. Relative \% of the answers from all respondents

\begin{tabular}{lccccc}
\hline Question & Strongly disagree & Disagree & Slightly agree & Agree & Strongly agree \\
\hline 1 & 17.11 & 40.79 & 27.63 & 10.53 & 3.94 \\
2 & 22.37 & 38.16 & 25 & 11.84 & 2.63 \\
3 & 3.95 & 27.63 & 34.21 & 27.63 & 6.58 \\
4 & 11.05 & 24.21 & 39.74 & 19.74 & 5.26 \\
5 & 19.74 & 38.16 & 28.95 & 7.89 & 5.26 \\
6 & 13.16 & 55.26 & 22.37 & 7.89 & 1.32 \\
7 & 2.63 & 35.53 & 46.05 & 14.47 & 1.32 \\
8 & 44.74 & 38.16 & 5.26 & 6.58 & 5.26 \\
9 & 5.26 & 32.89 & 35.53 & 22.37 & 3.95 \\
10 & 17.11 & 43.42 & 23.68 & 10.53 & 5.26 \\
11 & 26.32 & 40.79 & 19.74 & 10.53 & 2.62 \\
12 & 2.63 & 35.53 & 28.95 & 27.63 & 5.26 \\
\hline
\end{tabular}

The questions are listed in Table II $(N=76)$.

(Table III). The highest percentage of the people interviewed (40\%) slightly agreed that fire has impacts on resources and ecosystems. However, the majority (38\%) disagreed that fire causes irremediable and irrecoverable impacts, and 55\% disagreed with the statement that grassland fires have positive implications for agriculture and cattle activities. Nonetheless, they slightly agreed (46\%) that the vegetation recovers quickly. The majority of the respondents (45\%) strongly disagreed that fire has important social and economic implications in rural areas. Nevertheless, the majority $(36 \%)$ slightly agreed that the government should invest more funds to protect the ecosystems (Table III). The greatest percentage $(43 \%)$ of the respondents disagree that prescribed fire can be a good tool for landscape management and can reduce the probability of wildfires, $41 \%$ disagreed that prescribed fire is a better management tool than vegetation mechanical thinning, and 36\% disagreed that fire has negative impacts on biodiversity (Table III). On average, questions 1, 2, 5, 6, 8, 10 and 11 were ranked with 'disagree' (score between 1.50 and 2.50), while questions 3, 4, 7, 9 and 12 were rated with 'slightly agree' (score between 2.51 and 3.50 ). On average, question 3 ("fire causes problems in soil properties and fertility') had the highest agreement (mean score of 3.05), and question 8 ('fire causes important social and economic problems in rural areas') had the lowest agreement (mean score of 1.89; Table IV). Significant differences were identified among age groups and profession in questions 1, 2 and 3. The older respondents, farmers and foresters, agreed that fire is a threat or an ecological problem and that it has negative impacts on soil properties, in comparison with the group comprised of younger respondents and ecologists (Table IV). Significant differences were also identified in the answers to questions 4 and 5 according to age group and profession. The group consisting of younger respondents and ecologists thinks that fire has less negative impacts on resources and ecosystems and does not produce irremediable and irrecoverable impacts compared with the older respondents, farmers and foresters (Table IV). In question 6, no significant differences were observed among age groups. However, differences were observed among professions. The farmers more strongly agreed with the question 'grassland fires have positive impacts on agricultural and cattle activities' compared with ecologists and foresters. (Table IV). Significant differences were identified among age groups and profession in questions 7, 8 and 9. The old respondents and farmers rated that they agreed that vegetation recovers fast after the fire compared with the other groups. In relation to questions 8 and 9 , the older respondents and foresters agreed that fire causes important problems in rural areas and that the government should protect and invest more funds in measures against fire compared with younger respondents, ecologists, and farmers (Table IV). In question 10, no significant differences existed among age groups. Nonetheless, differences were observed among professions. The ecologists are more receptive to the idea that prescribed fire can be used for landscape management compared with foresters and farmers. Significant differences were also observed among different age groups and profession in question 11. The younger respondents, foresters and ecologists believe more than farmers that mechanical thinning is a better tool for landscape management than prescribed fire (Table IV). In the last question, significant differences were also found among age groups and profession. The older respondents, farmers and foresters more strongly agreed that fire has negative impacts on biodiversity than younger respondents and ecologists (Table IV).

The PCA grouped the studied variables according to the degree of correlation. This analysis allowed the degree of proximity/distance among variables to be identified. The first and second factor extracted from the PCA explained the majority of the variance $(64.29 \%)$. The PCA identified three groups: (i) questions 1, 2, 3, 4, 5, 8, 9 and, 12; (ii) questions 6 and 7; and iii) questions 10 and 11 (Figure 2a). The first factor had high positive scores for the questions in group $1(1,2,3,4,5,8,9$ and 12) and negative for questions of the third group (10 and 11), showing that they have a negative correlation. The second group (6 and 7) had high negative scores in the factor 3. The PCA did not identify any clear pattern in the type of answers according to the age group of the respondents (Figure 2b), but patterns existed in the case of the professions. In a global context, the 


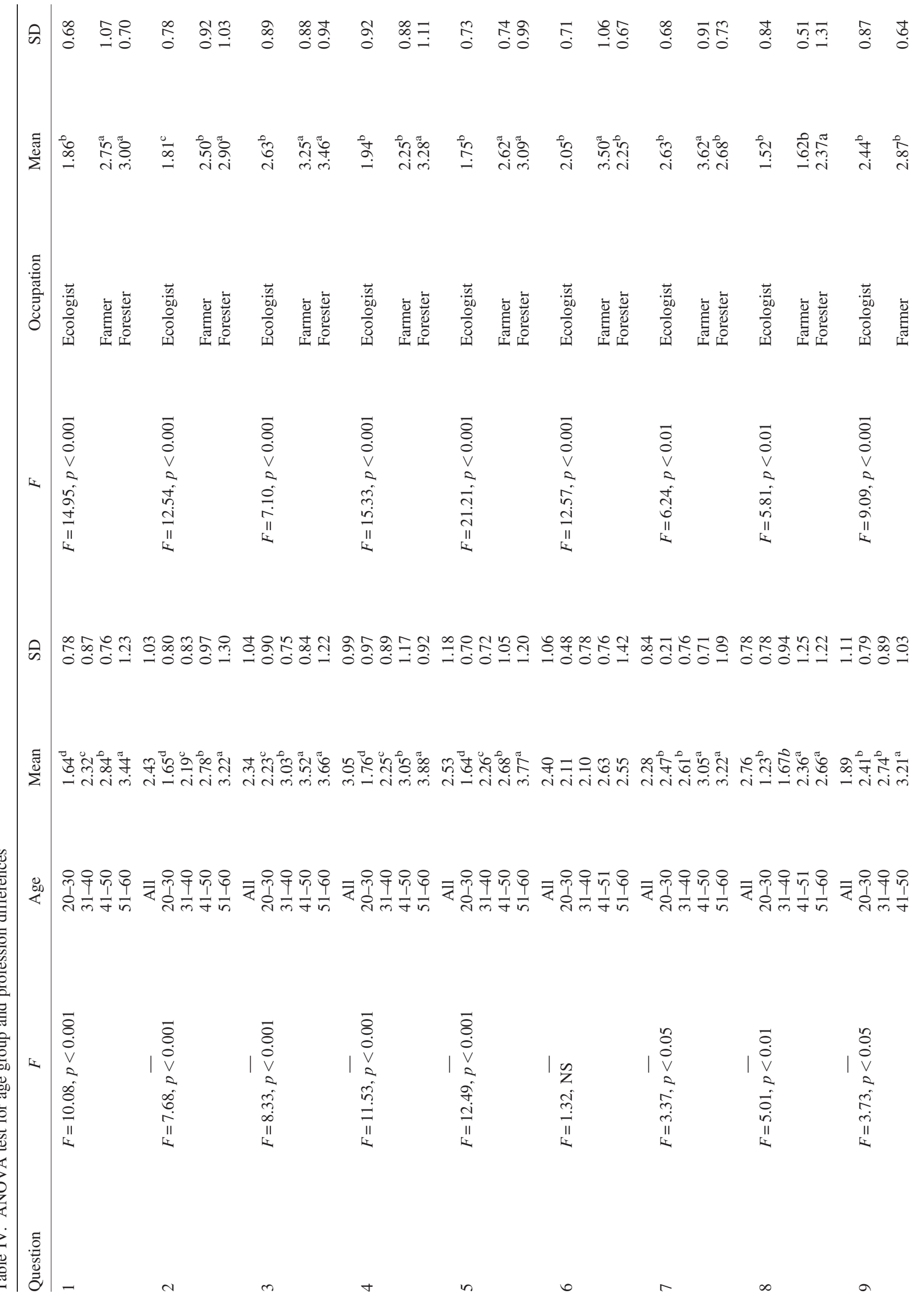




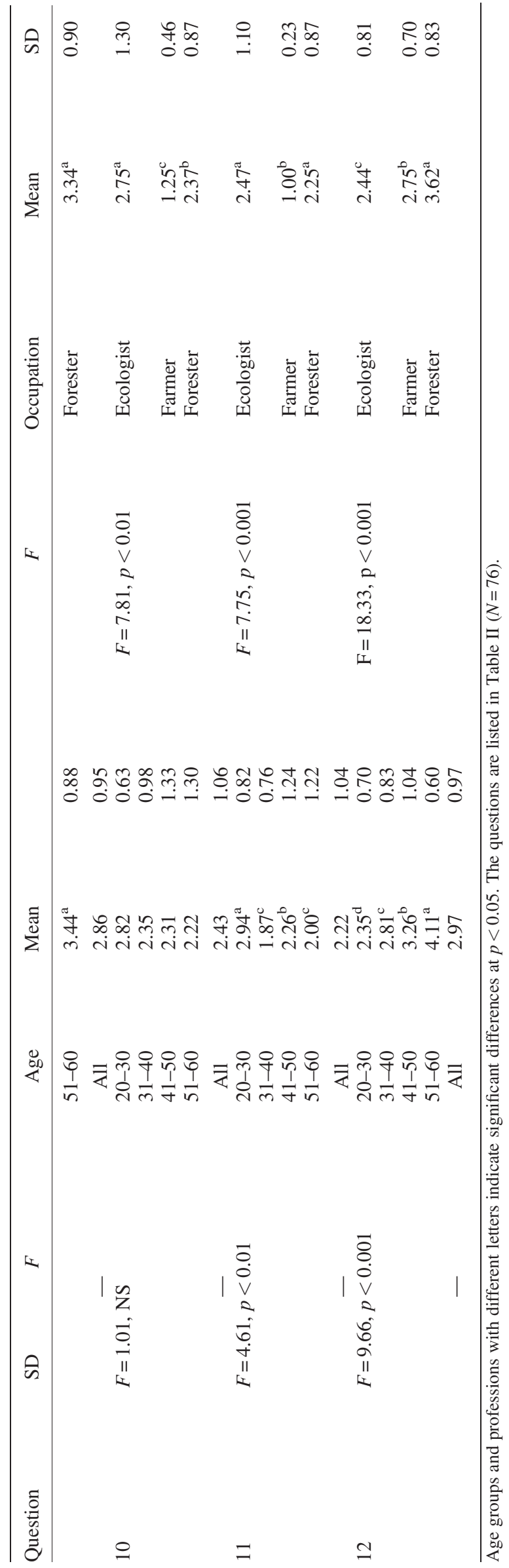

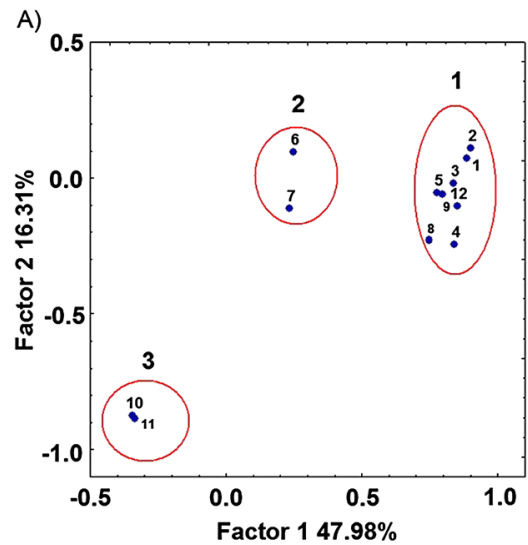
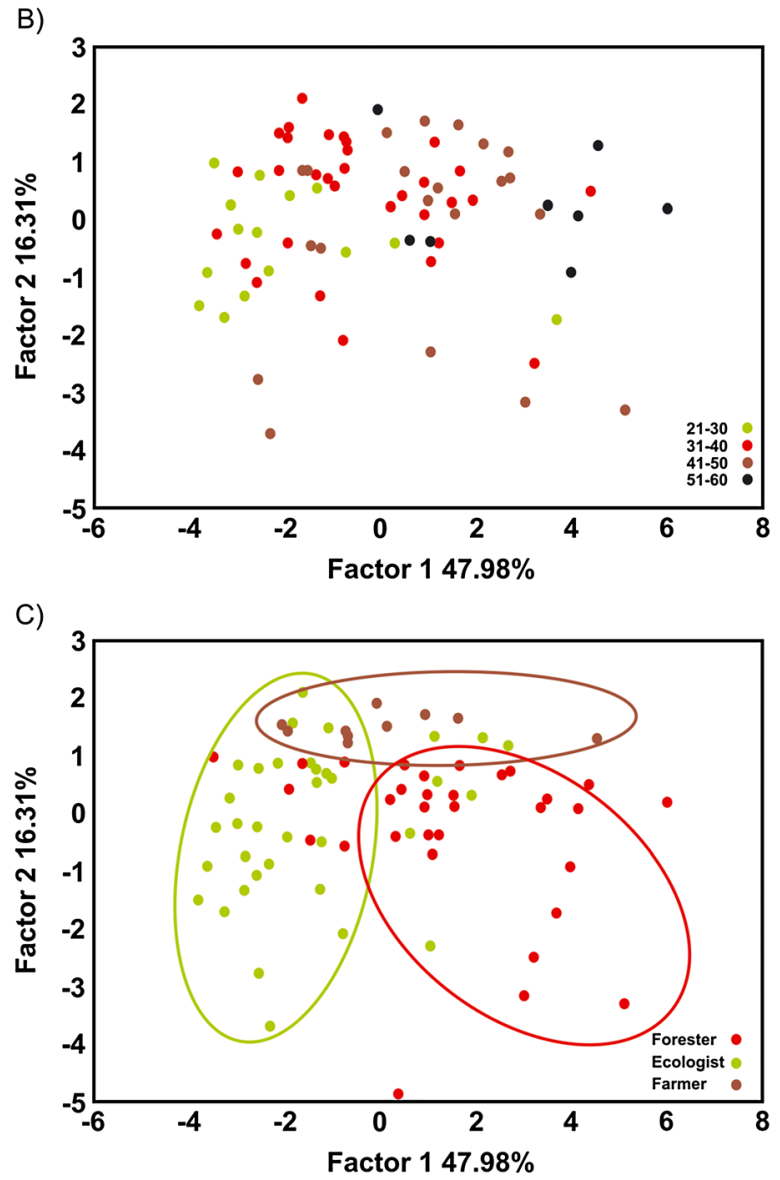

Figure 2. Relation between factor 1 and factor 2. (a) variables, ((b) and (c)) cases (panel b, according to respondent's age group and panel $\mathrm{c}$, according to respondent's occupation). Colour circumferences show the groups identified. This figure is available in colour online at wileyonlinelibrary.com/ journal/ldr

majority of the ecologists rated the questions carried out in this survey differently than the foresters and farmers (Figure 2c).

\section{DISCUSSION}

The majority of the respondents agreed that fire is not a serious threat to Lithuanian protected areas and ecosystems and does not have irremediable and irrecoverable impacts. 
Between 2002 and 2012, 6,101 forest fires occurred in Lithuania (average of 554 per year), which burned a total of 3,654 ha (average of 332 ha per year) (Lithuanian Environment Ministry, 2013). Fire is a common presence in European boreal forests and a powerful ecological force. In boreal ecosystems, fire severity is mainly low to moderate. The majority of the organic layer is not consumed, and trees survive after fire. Nowadays, because of the present fire suppression measures, the fire severity regime is very low. The return intervals are on average 60 to 120 years. Because of economic interests in forest products, a strong fire suppression policy has been implemented, reducing considerably the area burned (Granström, 2001; Dahlberg, 2002; Gromtsev, 2002). In Lithuania, the government made strong investments in fire suppression measures. For instance, in 2012, the state forest enterprises invested 5,048 thousand litas $(1$ euro $=3.45$ litas $)$ in the implementation and extension of anti-fire measurements. Several automatic ground-based surveillance systems were installed across the country to provide early detection to help fire fighters extinguish any fire (Lithuanian Environment Ministry, 2013). As result of this strong fire suppression policy, the effects of fire are very limited, and the perception of fire as a threat in Lithuania is reduced, and fire is not 'perceived' as an ecological problem. Nevertheless, these strong suppression policies may lead to the occurrence of disastrous wildfires because of fuel accumulation (Johnson et al., 2001). Fire and climate change models have shown that the fire season, frequency and severity will increase in European boreal ecosystems (Kilpelainen et al., 2010; de Groot et al., 2013). The combination of protecting the forests for economic interests and climate change may lead to the increase of the occurrence of destructive wildfires.

The stakeholders queried that they agreed that fire has an impact on protected area resources. This may be related to the importance of the forest sector to Lithuania. The impacts of fire in forested protected areas are strongly feared by Lithuanian stakeholders. Between 2002 and 2012, forest products represented a total of $3,964 \mathrm{~m}$ litas to the Lithuanian state (Lithuanian Environment Ministry, 2013). The respondents perceive that fires have negative impacts on soil properties and fertility and that grassland fires do not have positive implications for agriculture and cattle activities. In boreal ecosystems, fire impact depends on severity, litter thickness and the type of soil affected (Gromtsev, 2002). Czimczik et al. (2005) observed that low-severity fires contributed to the black carbon storage in podzols, meanwhile high-severity fires destroyed all organic matter. Boreal forest soils can store $1 \%$ of total carbon stock in boreal forests in the form of charcoal (Ohlson et al., 2009). Wikars \& Schimmel (2001) identified that immediately after a prescribed fire in a $P$. sylvestris forest, the mortality of invertebrates depends on the degree of organic matter consumption. Dahlberg (2002) observed that soil fungi can survive lowseverity fires, favouring some species and increasing soil biodiversity. Zackrisson et al. (1996) observed that the charcoal deposited by fire triggers important ecological processes with implications on long-term stand productivity and $\mathrm{N}$ cycling (Berglund et al., 2004). In Lithuania, Pereira et al. (2015a, 2015b) observed that immediately after a prescribed fire applied in a Calluna vulgaris heathland, soil $\mathrm{pH}$, organic matter, water repellency, extractable aluminium and zinc did not change significantly. Considering that fire in boreal regions burns mostly at low to moderate severity according to previously cited studies, from the scientific point of view, fire does not have detrimental impacts on soils. In European boreal environments, low-severity fires usually do not have effects on soil, and moderate fire severity decreases soil acidity and increases the amount of nutrients (Vanha-Majamaa et al., 2007).

The majority of the respondents agreed that vegetation recovers faster after the fire. Previous studies carried out by Pereira et al. (2013a, 2013b) observed that after spring grassland fires, the most common type in Lithuania, the vegetation recovered very quickly ( 1 to 2 months after), which is consistent with stakeholders' perceptions. In contrast, Marozas et al. (2007) observed that after a wildfire in a $P$. sylvestris and Betula pendula forest, herbaceous and dwarf vegetation took 5 to 6 years to recover, while moss took 9 years. After a low-severity fire in a $P$. sylvestris forest, Marozas et al. (2011) observed that ground vegetation recovered after 3-4 years to pre-fire levels. Schimmel \& Granström (1996) recorded that 5 years after a fire in a Swedish boreal ecosystem, the differences between vegetation cover in the control and the burned plot were significant, and the moss layer took 2 to 4 years to return to pre-fire levels.

The majority of the respondents argued that fire does not cause important economic and social costs in the rural areas inside the protected areas. Contrary to this perception, fires have significant impacts on the economy and social life of the rural areas. Between 2001 and 2011, the fire damage in industrial plantations cost 1.759 thousand litas, and in rural areas, the destruction of buildings cost 925 thousand litas. The reforestation costs were 2.092 thousand litas and management of burned areas (e.g. clean-up) 874 thousand litas (Lithuanian Statistical Survey, 2013). These numbers show that fires are an important socio-economical issue in rural areas in protected areas because they are also frequently affected by fires. One of the major factors of fire occurrence in protected areas is the existence of $P$. sylvestris plantations (Mindaugas Lapele, personal communication). It is widely known that monospecific plantations are more vulnerable to fire occurrence and severity than mixed forests (Pausas et al., 2009). Other reasons for these socio-economical costs may be the rural abandonment from Lithuanian protected areas (Pereira et al., 2012a). Despite the huge investment in fire suppression measures by the Lithuanian government, fire impacts are still important. As observed in other protected areas, fire suppression measures may be not the most effective options to reduce fire impacts. It is important that park stakeholders understand that when fires are suppressed, the opportunity may be lost to create natural fire breaks and decrease the severity of potential future fires (Miller \& Davies, 2009). 
The majority of the stakeholders slightly agreed that the government should invest more funds in protected area ecosystems to protect against fire. The majority of the respondents answered that prescribed fire was not a good tool for landscape management and to reduce the wildfire risk in protected areas. A previous survey of Lithuanian stakeholders about prescribed fire identified that $90 \%$ of the respondents would not give permission to apply it (Mierauskas \& Pereira, 2013). A recent study carried out in some European Mediterranean countries (Croatia, Cyprus, Greece, Italy, Portugal and Spain) by Raftoyannis et al. (2014) observed that foresters consider that fire suppression measures are more important than public awareness and fuel management. This opinion contrasts with the one from fire researchers, who argue that preventive measures such as prescribed fire are more effective than suppression actions. These results showed that protected areas' stakeholders, despite the scientific evidence, are still resistant to the use of fire for landscape management and the reduction of wildfire risk. Mierauskas \& Pereira (2013) observed that only 5\% of the Lithuanian stakeholders agreed with the use of prescribed fire in forests. The application of prescribed fires in forest environments is still very restricted (Fernandes, 2010). This lack of acceptance is connected to the misunderstanding of the role of fire in the ecosystems and/or effects on economic interests (Ryan et al., 2013).

Stakeholders have a negative perception about fire effects on forest resources. This may be the reason why the majority prefer landscape management with mechanical thinning rather than prescribed fire. This vision agrees with the present fuel reduction land management strategies in other European countries, which place a priority on mechanical thinning (Lazaro, 2010). Similar results were observed by Blanchard \& Ryan (2007) after a survey carried out on landscape management, where the respondents preferred vegetation removal with mechanical thinning rather than prescribed fire. Vogt et al. (2002) \& Winter et al. (2004) observed that acceptance of mechanical thinning or prescribed fire varied according to geographical area. In both studies, the respondents from California preferred mechanical thinning, those from Florida favoured the application of a prescribed fire, and those in Michigan were neutral. However, it is important to mention that mechanical thinning of vegetation and logging practices do not restore forest ecology and promote soil scarification. Mechanical thinning can offer temporary habitat to organisms that need fire. Nevertheless, it cannot create habitats for pyrophilous species that need soil and forest conditions only produced by fire. The vegetation removal can increase the effects of fire, such as soil heating and impacts on nutrient cycles. In addition, mechanical thinning compacts the duff layers of the soils producing one of the most dramatic changes in forest soils, increasing their vulnerability to erosion and promoting land and ecological degradation (Granström, 2001; Kauffman, 2004). On the other hand, low-severity prescribed fires in protected areas do not have negative implications on soil and vegetation (Nesmith et al., 2011; Pereira et al., 2015a, 2015b). Several studies have shown that prescribed fire alone or when combined with mechanical thinning is more effective in landscape management than mechanical thinning (Wayman \& North, 2007; Stephens et al., 2012). Ericsson et al. (2005) found an important decrease of key woodland habitats in south boreal Sweden since the mid-19 century, which it is attributed to the fire suppression measures and to the increase of logging practices.

The greater part of the respondents disagree that fire has negative impacts on the biodiversity of protected areas. According to studies carried out in European boreal ecosystems, this idea corresponds to reality. They showed that fire conserves and restores biodiversity. The most frequent type of fires, low to moderate severity, does not negatively affect the ecosystem but does have beneficial effects such as the increase of nutrient availability (Ryan, 2002; Vanha-Majamaa et al., 2007). In boreal forests, fire can contribute to the existence of many species of fungi, insects and vascular plants. Fires also keep areas opened and patchy, and many species depend upon these areas to germinate. High biodiversity is related to the presence of fire (Lindbladh et al., 2003). Parro et al. (2009) observed that fire can increase the biodiversity in humid areas and favour fire-adapted species, such as $C$. vulgaris or Molinia caerulea in dry habitats in Estonia. Lindbladh et al. (2003) found that rare beetle species richness increased in boreal forests after fire treatment. In Lithuania, Marozas et al. (2007) observed that fire had positive implications for $P$. sylvestris forest biodiversity.

The rating attributed to the questions was, considering all groups, classified as 'disagree' or 'slightly agree'. This suggests that, on average, the studied group did not support strongly the questions raised. The respondents 'disagreed' that fire is a relevant problem and did not cause social and economic problems in the protected areas. They do not have a positive view about prescribed fire application and its advantages in relation to mechanical thinning. The respondents 'slightly agree' that, when it occurs, fire can have negative implications on soil properties and fertility, protected area resources and biodiversity and that the government should invest more in protected area ecosystems against fire. Despite these negative views, they recognize that vegetation recovers quickly after the fire. In question 12 , the majority of the respondents disagreed that fire has impacts on biodiversity $(36 \%)$. However, the mean score for this question was 2.97 (Table IV), close to the value for 'slightly agree'. This difference was because of the high scores attributed by the older respondents (4.11) and farmers (3.62), which increased slightly the mean score.

The analysis of the diverse groups showed that older respondents and foresters considered fire as an important problem in Lithuania protected areas, fire has more irremediable impacts on the ecosystems and fire causes more social and economic problems. They support a high government investment in protected areas against fire and think that fire has more negative effects on biodiversity than younger respondents, farmers and ecologists. The ecologists have a 
higher acceptance of the application of prescribed fire but think that mechanical thinning is a more effective technique for landscape management. The farmers argued that fire has more positive impacts on agricultural and cattle activities and that vegetation grows faster after fire. Foresters, because of the economic interests in forest products, are less receptive to fire usage in protected area ecosystems. Gardner et al. (1985) also observed that foresters supported more fire suppression measures than prescribed fire application. Similarly, Raftoyannis et al. (2014) identified that prescribed fire application was not a very highly rated measure. The authors attributed this to the risks involved, the lack of the specific knowledge necessary to carry out this activity and the cost efficiency.

The PCA grouped the questions according to the respondent answers. Group 1 was mainly composed of the questions that evaluate the environmental, economic and social impacts of fire in Lithuania and the need for more investment for fire protection. The older respondents and foresters agreed with these questions. Group 2 consisted of the questions related to the beneficial aspects of fire, with strong agreement from older respondents and farmers. Group 3 is composed of questions 10 and 11, and ecologists and young respondents registered agreement with these statements about prescribed fire. The respondents that rated the questions of group 3 in categories indicating agreement rated questions of the group 1 in categories indicating less agreement. The groups were well defined in the case of the different occupations but not according to the age, showing in a global context that the visions about fire impacts on protected areas depend more on the profession.

The results suggest that ecologists and young respondents have a different view about fire impacts in the landscape. They are more tolerant of the use of fire in landscape management than foresters. Farmers are in an intermediate position. This also represents an increase of fire acceptance by the younger generation. In the future, stakeholders may be more open to discussing the application of fire to landscape management in protected areas. Education about fire's role in the ecosystem is important in order to raise awareness in various interest groups to promote a better acceptance of this fire use. Discussion among the different stakeholders and scientists has been claimed to be an important step in the acceptance of prescribed fire application, fire use in traditional activities and understanding the long-term benefits (Lazaro, 2010; Ryan et al., 2013; Fernandes et al., 2013). In this study, it was observed that, despite the interests of the respondents in protected area management, their current understanding about fire impacts on the landscape is in some cases different from the results from scientific studies. Raftoyannis et al. (2014) observed that foresters and researchers have different views regarding forest management. Foresters give more importance to fire suppression measures contrary to researchers that favour preventive activities. This highlights the necessity of connecting land managers with the results from science and the dissemination of research results in order to improve landscape management.

\section{CONCLUSIONS}

The stakeholders that were queried in this study understand that fire is not a threat or an ecological problem and does not reduce the biodiversity in Lithuanian protected areas. However, they slightly agree that fire can have impacts on soil properties and fertility and have negative consequences for protected area ecosystems and resources. Despite this, they do not consider that fire has an irremediable impact. The stakeholders do not agree that fire can be positive to agricultural and cattle activities. However, they understand that vegetation can recuperate quickly. Overall, they think that fire does not represent a social and economic problem to protected areas but desire more investment for fire suppression measures and do not accept prescribed fire as a management tool, preferring mechanical thinning.

The perception of the interviewed stakeholders is not shared by science results and data, especially on the topic of the impact of fire on soil properties and fertility, the positive aspects of grassland fires in agricultural and cattle activities, the social and economic aspects, the views about prescribed fire and its advantages in relation to mechanical thinning. Stakeholders' perceptions partially match research results on the topics of vegetation recovery and the fact that fire does not represent a threat or an ecological problem and does not reduce the biodiversity in the Lithuanian protected areas. Those visions depend upon the age group of the respondents but especially on their profession. Older respondents and foresters were more sceptical in relation to the fire's importance to the ecosystems and biodiversity and think that fire can be a bigger problem than ecologists and the younger respondents. Farmers understand better the benefits of fire in their activities. This represents an important generational change regarding the attitudes towards fire impacts on the ecosystems, but that depends on the protected area economic or conservation interests. Further studies will be done including more stakeholders and public opinion about fire impact in protected areas.

\section{ACKNOWLEDGEMENTS}

The authors like to acknowledge to the Lithuanian research council for financing the project LITFIRE, Fire effects on Lithuanian soils and ecosystems (MIP-48/2011). The authors appreciate the paper's English revision by Deborah Martin. We like to acknowledge the important help of two anonymous reviewers that increased importantly the paper quality.

\section{REFERENCES}

Aguilar S, Montiel C. 2011. The challenge of applying governance and sustainable development to wildland fire management in southern Europe. Journal of Forestry Research 22: 627-639. DOI: 10.1007/s11676-0110168-6

Aznar J, González-Pérez J, Badía D, Martí C. 2014. At what depth are properties of a gypseous forest topsoil affected by burning. Land Degradation \& Development. DOI: $10.1002 / \mathrm{ddr} .2258$ 
Berglund LM, DeLuca TH, Zackrisson O. 2004. Activated carbon ammendments to soil alters nitrification rates in Scots pine forests. Soil Biology and Biochemistry 36: 2067-2073. DOI: 10.1016/j. soilbio.2004.06.005

Bewket W, Sterk G. 2002. Farmers participation in soil and water conservation activities in the Chemoga Watershed, Blue Nile basin. Land Degradation \& Development 13: 189-200. DOI: 10.1002/ldr.492

Bisaro A, Kirk M, Zdruli P, Zimmermann W. 2014. Global drivers setting desertification research priorities: insights from a stakeholder consultation forum. Land Degradation \& Development 25: 5-16. DOI: 10.1002/ldr.2220

Blanchard B, Ryan R. 2007. Managing the wildland-urban interface in the Northeast: Perceptions of fire risk and hazard reduction strategies. Northern Journal of Applied Forestry 24: 203-208.

Bond WJ, Keeley JW. 2005. Fire as global "herbivore": The ecology and evolution of flammable ecosystems. Trends in Ecology \& Evolution 20: 387-394. DOI: 10.1016/j.tree.2005.04.025

Brockway DG, Outcalt KW. 2000. Restoring longleaf pine wiregrass ecosystems: Hexazinone application enhances effects of prescribed fire. Forest Ecology and Management 137: 121-1038. DOI: 10.1016/ S0378-1127(99)00321-7

Bukantis A 2001. Climatic fluctuations in Lithuania against a background of global warming. Acta Zoologica Lituanica 11: 113-120.

Carreiras M, Ferreira AJD, Valente S, Fleskens L, Gonzales-Pelayo Ó, Rubio JL, Stoof CR, Coelho COA, Ferreira CSS, Ritsema CJ. 2014. Comparative analysis of policies to deal with the wildfire risk. Land Degradation \& Development 25: 92-103. DOI: 10.1002/ldr.2274

Carvalho TM, Coelho COA, Ferreira AJD, Charlton CA 2002. Land degradation process in Portugal: Farmers perceptions of the application of agroforestry programmes. Land Degradation \& Development 13: 177-188. DOI: $10.1002 / \mathrm{ldr} .482$

Constanza JK, Moody A. 2011. Deciding where to burn: Stakeholder priorities for prescribing burning of a fire-dependent ecosystem. Ecology and Society 16: 14

Czimczik CI, Schmidt MWI, Schulze ED. 2005. Effects of increasing fire frequency on black carbon and organic matter in Podzols of Siberian Scots pine forests. European Journal of Soil Science 56: 417-428. DOI: $10.1111 / \mathrm{j} .1365-2389.2004 .00665 . x$

Dahlberg A. 2002. Effects of fire on Ectomycorrhizal fungi in Fennoscadian boreal forests. Silva Fennica 36: 69-80.

Davies GM, Pollard L, Mwenda MD. 2010. Perceptions of landdegradation, forest restoration and fire management: A study from Malawi. Land Degradation \& Development 21: 546-556. DOI: 10.1002/ldr.995

De Groot WJ, Flannigan MD, Cantin AS. 2013. Climate change impacts on future boreal regimes. Forest Ecology and Management 294: 35-44. DOI: $10.1016 /$ j.foreco.2012.09.027

De Pina Tavares J, Ferreira AJD, Reis EA, Baptista I, Amoros R, Costa L, Furtado AM, Coelho C. 2014. Appraising and selecting strategies to combat and mitigate desertification based on stakeholder knowledge and global best practices in Cape Verde Archipielago. Land Degradation \& Development 25: 45-57. DOI: 10.1002/ldr.2273

Donovan GH, Prestemon JP, Gebert K. 2011. The effect of newspaper coverage and political pressure on wildfire suppression costs. Society \& Natural Resources 24: 785-798. DOI: 10.1080/08941921003649482.

Ericsson TS, Berglund H, Ostlund L. 2005. History and biodiversity of woodland key habitats in south boreal Sweden. Biological Conservation 122: 289-303. DOI: 10.1016/j.biocon.2004.07.019

Fernandes P. 2010. Scientific knowledge and operational tools to support prescribed burning: Recent developments. In Towards integrated fire management - outcomes of the European project Fire Paradox, Sande Silva J, Rego F, Fernandes P, Rigolot E (eds). European Forest Institute Research Report. European Forest Institute: Joensuu; 152-159.

Fernandes PM, Davies GM, Ascoli D, Fernandez C, Moreira F, Rigolot E Stoof CR, Vega JA, Molina D. 2013. Prescribed burning in southern Europe: developing fire management in a dynamic landscape. Frontiers in Ecology and the Environment 11: e4-e14. DOI: 10.1890/120298.

Flannigan MD, Krawchuk MA, de Groot WJ, Wotton BM, Gowman LM. 2009. Implications of changing climate for global wildland fire. International Journal of Wildland Fire 18: 483-507. DOI: 10.1071/WF08187.

Fleskens L, Stringer LC. 2014. Land management and policy responses to mitigate desertification and land degradation. Land Degradation \& Development 25: 1-4. DOI: $10.1002 / \mathrm{ldr} .2272$

Gadgil RL, Ede FJ. 1998. Application of scientific principles to sand dune stabilization in New Zealand: past progress and future needs. Land
Degradation \& Development 9: 131-142. DOI: 10.1002/(SICI)1099145X(199803/04)9:2<131::AID-LDR286>3.0.CO;2-H

Ganteaume A, Camia A, Jappiot M, San-Miguel-Ayanz J, Long-Furnel M, Lampin C. 2013. A review of the main driving factors of forest fire ignition over Europe. Environmental Management 51: 651-662. DOI: 10.1007/s00267-012-9961-z

Gardner PD, Cortner HJ, Widaman KF, Stenberg KJ. 1985. Forest-user attitudes toward alternative fire managemet policies. Environmental Management 9: 303-312.

Granström A. 2001. Fire management for biodiversity in the European boreal forest. Scandinavian Journal of Forest Research 16: 62-69. DOI: $10.1080 / 028275801300090627$

Gromtsev A. 2002. Natural disturbance Dynamics in the boreal forests of European Russia: A Review. Silva Fennica 36: 41-55.

Johnson EA, Miyanishi K, Bridge SRJ. 2001. Wildfire regime in the boreal forest and the idea of suppression and fuel buildup. Conservation Biology 15: 1554-1557. DOI: 10.1046/j.1523-1739.2001.01005.x

Jones N, de Graaff J, Duarte F, Rodrigo I, Poortinga A. 2014. Farming systems in two less favoured areas in Portugal: their development from 1989 to 2009 and the implication for sustainable land management. Land Degradation \& Development 25: 29-44. DOI: 10.1002/ldr.2257

Karltun E, Lemenih M, Tolera M. 2013. Comparing farmers' perception of soil fertility change with soil properties and crop performance in Beseku, Ethiopia. Land Degradation \& Development 23: 228-235. DOI: 10.1002/ldr. 1118

Kauffman JB. 2004. Death rides the forest: Perceptions of fire. Land use and ecological restoration of western forests. Conservation Biology 4: 878882. DOI: $10.1111 /$ j.1523-1739.2004.545_1.x

Kilpelainen A, Kellomaki S, Strandman H, Venalainen A. 2010. Climatic change impacts on forest fire potential in boreal conditions in Finland. Climatic Change 103: 383-398. DOI: 10.1007/s10584-009-9788-7

Lazaro A. 2010. Development of prescribed burning and suppression fire in Europe. In Best practices in fire use - Prescribed burning and suppression fire programs in selected case-study regions in Europe, Montiel C, Kraus D (eds). European Forest Institute Research Report. European Forest Institute: Joensuu; 17-31.

Lazaro C, Montiel C. 2010. Overview of prescribed burning policies and practices in Europe and other countries. In Towards integrated fire management - outcomes of the European project Fire Paradox, Sande Silva J, Rego F, Fernandes P, Rigolot E (eds). European Forest Institute Research Report. European Forest Institute: Joensuu; 137-150.

Lindbladh M, Nikalsson M, Nilsson SG. 2003. Long-time record of fire and open canopy in a high biodiversity forest in southeast Sweden. Biological Conservation 114: 231-243. DOI: 10.1016/S0006-3207(03)00043-0.

Lithuanian Environment Ministry (2013) Lithuanian State Forests 2012 2013. ftp://195.182.70.69/incoming/www/Valstybiniai_miskai/Leidiniai/ 2012_2013_Lithuanian_state_forests.pdf (Accessed in 2013-10-01).

Lithuanian Statistical Survey. 2013. http://www.osp.stat.gov.lt (Accessed in 2013-10-12).

Marozas V, Plausinyte E, Augustaitis A, Kaciulyte A. 2011. Changes of ground vegetation and tree-ring growth after surface fires in Scots pine forests. Acta Biologica Universitatis Daugavpilensis 11: 156-162.

Marozas V, Racinskas J, Bartkevicius E. 2007. Dynamics of ground vegetation after surface fires in hemiboreal Pinus sylvestris forests Forest Ecology and Management 250: 47-55. DOI: 10.1016/j. foreco.2007.03.008

Martinez J, Vega-Garcia C, Chuvieco E. 2009. Human-caused wildfire risk rating for prevention in Spain. Journal of Environmental Management 90: 1241-1252. DOI: 10.1016/j.jenvman.2008.07.005.

Mavsar R, Gonzalez Caban A, Farreras V. 2010. The importance of economics in fire management programmes analysis. In Towards integrated fire managemet - outcomes of the European project Fire Paradox, Sande Silva J, Rego F, Fernandes P, Rigolot E (eds). European Forest Institute Research Report. European Forest Institute: Joensuu; 93-103.

Mcdonagh J, Lu Y, Semalulu O. 2014. Adoption and adaptation of improved soil management practices in the Eastern Ugandan Hills. Land Degradation \& Development 25: 58-70. DOI: 10.1002/ldr.1143

Mekuria W, Aynekulu E. 2013. Exclosure land management for restoration of the soils in degrade communal grazing lands in Northern Ethiopia. Land Degradation \& Development 24: 528-538. DOI: $10.1002 / \mathrm{ldr} .1146$

Meyn A, White PS, Buhk C, Jentsch A. 2007. Environmental drivers of large, infrequent wildfires: the emerging conceptual model. Progress in Physical Geography 31: 287-312. DOI: 10.1177/ 0309133307079365 
Michels A, DeGraaf L. 2010. Examining Citizen participation: Local participatory policy making and democracy. Local Government Studies 36: 477-491. DOI: 10.1080/03003930.2010.494101

Mierauskas P, Pereira P. 2013. Stakeholders perception about prescribed fire use in Lithuania. First results. Flamma 4: 156-161.

Mierauskas P. 2012. Policy and legislative framework overview of fire management in Lithuanian protected areas. Flamma 3: 1-5.

Miller C, Davies B. 2009. Quantifying the consequences of fire suppression in two Californian national parks. The George Miller Forum 26: 76-88.

Moreno MV, Conedera M, Chuvieco E, Pezzati GB. 2014. Fire regime changes and major driving forces in Spain from 1968 to 2010. Environmental Science \& Policy 37: 11-22. DOI: 10.1016/j.envsci.2013.08.005

Mulale K, Chanda R, Perkins JS, Magole L, Sebego RJ, Atlhopheng JR, Mphinyane W, Reed MS. 2014. Formal institutions and their role in promoting sustainable land management. Land Degradation \& Development 25: 80-91. DOI: 10.1002/ldr.2274

Nabahungu NL, Visser SM. 2013. Farmers' knowledge and perception of agricultural wetland management in Rwanda. Land Degradation \& Development 24: 363-374. DOI: 10.1002/ldr.1133

Nesmith JCB, Caprio AC, Pfaff AH, McGinnis TW, Keeley JE. 2011. A comparison of the effects from prescribed fire and wildfires managed for resource objectives in Sequoia and Kings Canyon National Parks. Forest Ecology Management 261: 1275-1282. DOI: 10.1016/j. foreco.2011.01.006.

Novara A, Gristina L, Bodi MB, Cerdà A. 2011. The impact of fire on redistribution of soil organic matter on a mediterranean hillslope under maquia vegetation type. Land Degradation \& Development 22: 530-536. DOI: 10.1002/ldr.1027

Ohlson M, Dahlberg B, Okland T, Brown KJ, Halvorsen R. 2009. The charcoal pool in boreal forest soils. Nature Geoscience 2: 692-696. DOI:10.1038/ngeo617

Özgüner H, Eraslan S, Yilmaz Y. 2012. Public perception of landscape restoration along degraded urban streamside. Land Degradation \& Development 23: 24-33. DOI: 10.1002/ldr.1043

Parro K, Koster K, Jogiste K, Vodde F. 2009. Vegetation Dynamics in a fire damaged area: The major ground vegetation species. Baltic Forestry 15: 206-215.

Pausas JG, Keeley JE. 2009. A burning story: The role of fire in history of life. Bioscience 59: 593-601. DOI: 10.1525/bio.2009.59.7.10.

Pausas JG, Llovet J, Rodrigo A, Vallejo R. 2009. Are wildfires a disaster in the Mediterranean basin? - A review. International Journal of Wildland Fire 17: 713-723. DOI: 10.1071/WF07151.

Pereira P, Cerdà A, Jordán A, Bolutiene V, Úbeda X, Pranskevicius M, Mataix-Solera J. 2013a. Spatio-temporal vegetation recuperation after a grassland fire in Lithuania. Procedia Environmental Sciences 19: 856-864. DOI: 10.1016/j.proenv.2013.06.095.

Pereira $\mathrm{P}$, Cerdà A, Úbeda X, Mataix-Solera J, Jordán A, Burguet M. 2013b. Spatial models for monitoring the spatio-temporal evolution of ashes after fire - a case study of a burnt grassland in Lithuania. Solid Earth 4: 153-165. DOI:10.5194/se-4-153-2013

Pereira P, Úbeda X, Martin DA, Mataix-Solera J, Oliva M, Novara A. 2013c. Short-term spatio-temporal spring grassland fire effects on soil colour organic matter and water repellency in Lithuania. Solid Earth Discussions 5: 2119-2154. DOI:10.5194/sed-5-2119-2013

Pereira P, Lapele M, Mierasukas P. 2012a. Protected areas management with prescribed fire in Lithuania. The case of Dzukija National Park. Flamma 3: 1-5.

Pereira P, Mierauskas P, Úbeda X, Mataix-Solera J, Cerdà A 2012b. Fire in protected areas - the effect of protection and importance of fire management. Environmental Research, Engineering and Management 1: 52-62. DOI: $10.5755 / \mathrm{j} 01$ erem.59.1.856.

Pereira P, Pranskevicius M, Bolutiene V, Jordán A, Zavala L, Úbeda X, Cerdà A. 2015a. Short term spatio-temporal variability of soil water extractable $\mathrm{Al}$ and $\mathrm{Zn}$ after a low severity grassland fire in Lithuania. Flamma 6: 50-57.

Pereira P, Pranskevicius M, Bolutiene V, Jordán A, Zavala L, Úbeda X, Cerdà A. 2015b. Short-term impact of prescribed fire on soil $\mathrm{pH}$, organic matter and hydrophobicity in a Calluna vulgaris heathland located in Lithuania. First results. Flamma 6: 13-19.

Pereira P, Úbeda X, Mataix-Solera J, Cerdà A. 2010. Forest management with prescribed fire. Opportunities and barriers. Darnus Vystymosi Strategia ir Pratica 1: 81-95.

Pérez-Cabello F, Ibarra P, Echeverria MT, de la Riva J. 2010. Post-fire land degradation of Pinus sylvestris L. woodlands after 14 years. Land Degradation \& Development 21: 145-160. DOI: 10.1002/ldr.925
Raftoyannis Y, Nocentini S, Marchi E, Sainz RC, Guemes CC, Pilas I, Peric S, Paulo JA, Moreira-Marcelino AC, Costa-Ferreira M, Kakouris E, Lindner M. 2014. Perceptions of fire experts on climate change and fire management in European Mediterranean forests. iForest-Biogeosciences and Forestry 7: 33-41. DOI: 10.3832/ifor0817-006

Reed MS, Dougill AJ, Taylor MJ. 2007. Integrating local and scientific knowledge for adaptation to land degradation: Kalahari rangeland management options. Land Degradation \& Development 18: 249-268. DOI: $10.1002 /$ ldr.777

Reed MS. 2008. Stakeholder participation for environmental management: A literature review. Biological Conservation 141: 2417-2431. DOI: 10.1016/j.biocon.2008.07.014

Reynolds JF, Grainger A, Stafford Smith DM, Bastin G, Garcia-Barrios L, Fernández RJ, Janssen MA, Jürgens N, Scholes RJ, Veldkamp A, Verstraete MM, Maltitz GV, Zdruli P. 2011. Scientific concepts for an integrated analysis. Land Degradation \& Development 22: 166-183. DOI: 10.1002/ldr.1104

Republic of Lithuania law on protected areas, December 2011, No IX-628.

Riano D, Chuvieco E, Ustin S, Zomer R, Dennison P, Roberts D, Salas J. 2002. Assessment of vegetation regeneration after fire through multitemporal analysis of AVIRIS images in the Santa Monica mountains. Remote Sensing of Environment 79: 60-71. DOI: 10.1016/S00344257(01)00239-5.

Ryan KC, Knaap EE, Varner JM. 2013. Prescribed fire in North American forests and woodlands: history, current practice, and challenges. Frontiers in Ecology and the Environment 11: e15-e24. DOI: 10.1890/ 120329.

Ryan KC. 2002. Dynamic interactions between forest structure and fire behaviour in Boreal Ecosystems. Silva Fenica 36: 13-19.

Ruiz-Mirazo J, Martinez-Fernandez J, Vega-Garcia C. 2012. Pastoral wildfires in the Mediterranean: Understanding their linkages to land cover patterns in managed landscapes. Journal of Environmental Management 98: 43-50. DOI: 10.1016/j.jenvman.2011.12.017.

Schimmel J, Granström A. 1996. Fire severity and vegetation response in the boreal Swedish forest. Ecology 77: 1436-1450.

Sop TK, Oldeland J. 2013. Local perceptions of woody vegetation dynamics in the context of a 'Greenning Sahel': A case study from Burkina Faso. Land Degradation \& Development 24: 511-527. DOI: 10.1002/ ldr. 1144

State Service of Protected Areas under the Ministry of Environment. 2013. Statistics of the Protected Areas. http://www.vstt.lt/VI/index.php\#r/188 (Accessed in 28-01-2014).

State Service of Protected Areas under the Ministry of Environment 2012. Protected Areas and Biodiversity. http://www.amvmt.lt/images/veikla/stat/ miskustatistika/2012/03\%20Misku\%20ukio\%20statistika\%202012_m.pdf (Accessed in 28-01-2014).

Stephens SL, McIver JD, Boerner REJ, Fettig CJ, Fontaine JB, Hartsough BR, Kennedy PL, Schwilk DW. 2012. The effects of forest fuel reduction. BioScience 62: 549-560. DOI: 10.1525/bio.2012.62.6.6

Stephens SL, Moghaddas JJ. 2005. Silvicultural and reserve impacts on potential fire behaviour and forest conservation: Twenty-five years of experience from Sierra Nevada mixed conifer forests. Biological Conservation 125: 369-379. DOI: 10.1016/j.biocon.2005.04.007.

Stone KR, Pillod DS, Dwire KA, Rhoades CC, Wollrab SP, Young MK. 2010. Fuel reduction management practices in riparian areas of the western USA. Environmental Management 46: 91-100. DOI: 10.1007/ s00267-010-9501-7

Stringer LC, Harris A. 2013. Land degradation in the Dolj county, southern Romania: Environmental changes, impacts and responses. Land Degradation \& Development 25: 17-28. DOI: 10.1002/ldr.2260

Tesfaye A, Negatu W, Brouwer R, van der Zaag P. 2014. Understanding soil conservation decision of farmers in the Gedeb watershed, Ethiopia. Land Degradation \& Development 25: 71-79. DOI: 10.1002/ldr. 2187

Turner MD. 1999. No space for participation: pastorialist narratives and the etiology of park-herder conflict in southeasthern Niger. Land Degradation \& Development 10: 345-363. DOI: 10.1002/(SICI)1099-145X (199907/08)10:4<345::AID-LDR358>3.0.CO;2-8

Van Berkel DB, Carvalho-Ribeiro S, Verburg PH, Lovett A. 2011. Identifying assets and constrains for rural development with qualitative scenarios. Landscape and Urban Planning 102: 127-141. DOI: 10.1016/j. landurbplan.2011.03.016

Vanha-Majamaa I, Lija S, Ryoma R, Kotiaho JS, Laaka-Lindberg S, Lindberg H, Puttonen P, Tamminen P, Toivanen T, Kuuluvainen T. 2007. Rehabilitating boreal forest structure and species composition in 
Finland through logging, dead wood creation and fire: The EVO experiment. Forest Ecology and Management 250: 77-88. DOI: 10.1016/j. foreco.2007.03.012

Vogt C, Winter G, Fried J. 2002. Antecedents and attitudes toward prescribed burning, mechanical thinning, and defensible space fuel reduction. In: Homeowners, communities, and wildfires: Science findings from the national fire plan. Proceedings of the ninth International Symposium on Society and Resources Management, Jakes P (ed.). North Central Research Station Forest Service U.S. Department of Agriculture: St. Paul; 74-83.

Wayman RB, North M. 2007. Initial response of a mixed-conifer understory plant community to burning and thinning restoration treatments. Forest Ecology and Management 239: 32-44. DOI: 10.1016/j.foreco.2006.11.011
Wikars LO, Schimmel J. 2001. Immediate effects of fire-severity on soil invertebrates in a cut and uncut pine forests. Forest Ecology and Management 141: 189-200. DOI: 10.1016/S0378-1127(00) 00328-5

Winter G, Vogt CA, McCaffrey S. 2004. Examining social trust in fuels management strategies. Journal of Forestry 102: 8-15.

Zackrisson O, Nilsson MC, Wardle DA. 1996. Key ecological function of charcoal from wildfire in the Boreal forest. Oikos 77: 10-19.

Zaksek M, Arvai JL. 2004. Toward improved communication about wildland fire: mental models research to identify information needs for natural resource management. Risk Analysis 24: 1503-1541. DOI: 10.1111/ j.0272-4332.2004.00545.x 